Article

\title{
Cynomolgus Monkeys (Macaca fascicularis) as an Experimental Infection Model for Human Group A Rotavirus
}

\author{
Gentil Arthur Bentes ${ }^{1, *(\mathbb{D})}$, Juliana Rodrigues Guimarães ${ }^{1}$, Eduardo de Mello Volotão ${ }^{2}$, \\ Alexandre Madi Fialho ${ }^{2}$, Cleber Hooper ${ }^{3}$, Ana Carolina Ganime ${ }^{2}$, Noemi Rovaris Gardinali ${ }^{1}$, \\ Natália Maria Lanzarini ${ }^{1}$, Alexandre dos Santos da Silva ${ }^{1}$, Jacob Pitcovski ${ }^{4}$, José Paulo Leite ${ }^{2}$ \\ and Marcelo Alves Pinto ${ }^{1}$ \\ 1 Laboratório de Desenvolvimento Tecnológico em Virologia, Instituto Oswaldo Cruz, Fiocruz, \\ Rio de Janeiro/RJ 21.040-360, Brazil; juliana.guimaraes@ioc.fiocruz.br (J.R.G.); \\ no_rovaris@yahoo.com.br (N.R.G.); natalial@ioc.fiocruz.br (N.M.L.); alexsantos@ioc.fiocruz.br (A.d.S.d.S.); \\ marcelop@ioc.fiocruz.br (M.A.P.) \\ 2 Laboratório de Virologia Comparada e Ambiental, Instituto Oswaldo Cruz, Fiocruz, \\ Rio de Janeiro/RJ 21.040-360, Brazil; volotao@ioc.fiocruz.br (E.d.M.V.); amfialho@ioc.fiocruz.br (A.M.F.); \\ carolganime@gmail.com (A.C.G.); jpgleite@ioc.fiocruz.br (J.P.L.) \\ 3 Serviço de Controle da Qualidade Animal, Instituto de Ciência e Tecnologia em Biomodelos, Fiocruz, \\ Rio de Janeiro/RJ 21.040-360, Brazil; cleber.hooper@fiocruz.br \\ 4 Virology and Vaccine Development Laboratory, MIGAL Technology Center, Kiryat Shmona 11016, Israel; \\ jp@migal.org.il \\ * Correspondence: gentilbentes@fiocruz.br; Tel.: +55-21-2562-1711
}

Received: 20 March 2018; Accepted: 27 April 2018; Published: 4 July 2018

\begin{abstract}
Group A rotaviruses (RVA) are one of the most common causes of severe acute gastroenteritis in infants worldwide. Rotaviruses spread from person to person, mainly by faecal-oral transmission. Almost all unvaccinated children may become infected with RVA in the first two years of life. The establishment of an experimental monkey model with RVA is important to evaluate new therapeutic approaches. In this study, we demonstrated viral shedding and viraemia in juvenile-adult Macaca fascicularis orally inoculated with Wa RVA prototype. Nine monkeys were inoculated orally: seven animals with human RVA and two control animals with saline solution. During the study, the monkeys were clinically monitored, and faeces and blood samples were tested for RVA infection. In general, the inoculated animals developed an oligosymptomatic infection pattern. The main clinical symptoms observed were diarrhoea in two monkeys for three days, associated with a reduction in plasmatic potassium content. Viral RNA was detected in seven faecal and five sera samples from inoculated animals, suggesting virus replication. Cynomolgus monkeys are susceptible hosts for human Wa RVA infection. When inoculated orally, they presented self-limited diarrhoea associated with presence of RVA infectious particles in faeces. Thus, cynomolgus monkeys may be useful as animal models to evaluate the efficacy of new antiviral approaches.
\end{abstract}

Keywords: human group A rotaviruses; cynomolgus monkeys; experimental infection model

\section{Introduction}

Acute gastroenteritis (AG) is one of the leading infectious diseases worldwide, and group A rotaviruses (RVA) is one of the principal causative agents of this illness [1]. RVA vaccines are one of the most efficient strategies to reduce both mortality and hospitalisation due to severe AG [2]. Oral attenuated vaccines are developed to mimic the natural effect of infection and to prevent acute 
diseases [3]. Currently, two attenuated oral vaccines, one pentavalent (RotaTeq ${ }^{\circledR}$, Merck \& Co, Inc., Kenilworth, NJ, USA) and another monovalent (Rotarix ${ }^{\circledR}$, GlaxoSmithKline Biologicals, Rixensart, Belgium), are licensed and available in several countries [3]. A review study reported a decline of $49-89 \%$ in rotavirus hospital care in children under five years in the first two years of vaccine introduction [4]. Although almost all adults have antibodies to rotavirus, they may still be susceptible to infection, and cases of reinfections are very common, due to several escape mechanisms from the host immune system and viral genetic variability $[5,6]$. Control of acute rotavirus gastroenteritis focuses on the treatment and prevention of dehydration, relief of symptoms and clinical signals, and restoration of normal physiological functioning [3].

Many animal models have been used to help understand the mechanisms of RVA immunity and pathogenesis, including lambs [7], calves [8], gnotobiotic piglets [9-11], rabbits [12], mice [13], rats [14], and recently organoids [15]. Considering that non-human primates are the most closely related animals to humans, there is a lack of information available about their susceptibility to human RVA, although they are likely to be naturally infected with simian RVA [16,17]. Although group A rotaviruses are species-specific, there is evidence suggesting the occurrence of interspecies transmission in nature and experimental infection [18-20]; however, compared with the vast majority of natural isolates obtained from any species, virulence of prototype Wa RVA has been associated with reduced clinical signs in heterologous hosts [21,22]. However, little has been achieved to date in attempting to develop non-human primate models for RVA infection and AG. Therefore, to establish an experimental infection model for human RVA and AG in non-human primates, it would be crucial to understand the heterologous rotavirus infection in order to conduct future vaccine trials and immunotherapy tests. It is important to emphasise that previous studies were performed on neonatal and infant monkeys [23-26], translating the importance of RVA infection in patients under 5 years old. However, studies about the pathogenesis of RVA infection in adult patients are neglected by other authors due to the reduced incidence of clinical symptoms in infected persons, but this represents an important factor to maintaining the virus in the environment [27].

In the present report, we describe a successful experimental infection of adult cynomolgus monkeys (Macaca fascicularis) using Wa RVA prototype to evaluate the susceptibility and pathogenesis of this species as a model for RVA infection and AG. In our hypothesis, RVA infection in adult cynomolgus monkey presents a similar gastroenteritis pattern to that observed in hospitalized adult patients: the severity of enteric disease is variable, depending on the individual immunological background [28], also reported as RVA nosocomial infection in adult patients [29]. Additionally, other authors suggest that caregivers (mother/grandmother/older siblings) may get infected through young children or may act as carriers for transmission, reinforcing the role of adult patients [27]. Also, immunodeficient adults have a higher risk of onset of symptoms and prolonged dissemination of the virus, reaching a year or more, thus representing a powerful reservoir of infection; a fact already described in immunodeficient children [30,31].

\section{Materials and Methods}

\subsection{Animals}

Nine clinically healthy male cynomolgus monkeys, with ages ranging from 32 months (2 years 8 months) to 105 months (8 years 9 months), weighing from 2.35 to $6.72 \mathrm{~kg}$ (Table 1), were screened for RVA by serological and molecular assays during a quarantine period. All animals were obtained from the Primatology Department of the Institute of Science and Technology in Biomodels (ICTB) of the Oswaldo Cruz Foundation (Fiocruz), Rio de Janeiro, RJ, Brazil at Animal Biohazard Level 2 facilities during quarantine and throughout the whole experiment. Animals were individually housed in stainless steel squeeze-back cages $(0.77 \mathrm{~m}$ height $\times 0.60 \mathrm{~m}$ width $\times 0.68 \mathrm{~m}$ depth $)$ in climate-controlled rooms (temperature of $23 \pm 1{ }^{\circ} \mathrm{C}$ and humidity $55 \pm 5 \%$ ) with a $12 \mathrm{~h}$ light/dark cycle and fed daily with commercial primate diet supplement, fresh fruits and vegetables. Water was 
provided ad libitum. Housing standard adopted in our study adhered to space recommendations for individually non-human primates with a maximum weight of $7 \mathrm{~kg}$, in accordance with the Brazilian Normative Resolution CONCEA n.28, of 13 November 2015 (http: / / www.mct.gov.br/upd_blob /0240/ 240230.pdf). The origin of the primate colony and animals' maintenance were previously described [32]. All animals had health certificates, which guaranteed the absence of infectious diseases, and were confirmed to be seronegative for RVA immunoglobulins by in-house immunoassay. A serological survey confirmed that they were free of simian immunodeficiency virus (SIV) and simian type D retrovirus (SRV/D) [33]. Cynomolgus monkeys were used in this study because of our expertise with Macaca fascicularis used in experimental infection [34-36].

Fiocruz Ethics Commission for the Use of Animals approved the experimental protocol on 26 September 2011 (CEUA-Fiocruz LW-35/11). Monkeys were monitored by veterinarians and technicians in procedures and daily for ataxia, dehydration and weight loss. If any monkey developed severe gastroenteritis, in which there was significant decrease in weight and ataxia, this animal would be euthanized to reduce suffering/pain. Clinical procedures were performed under anaesthesia, and all efforts were made to minimize painful procedures. The study protocol was conducted in strict accordance with the recommendations from the Guide for Care and Use of Laboratory Animals of the Brazilian Society of Science in Laboratory Animals (SBCAL) and the National Council for the Control of Animal Experimentation (CONCEA, Brazil).

\subsection{Virus Inoculum}

Human RVA was used as virus inoculum (RVA/human-tc/USA/Wa/1974/G1P[8]), inoculated in cell culture using monkey African green kidney cells at passage \#58 (MA-104, ATCC ${ }^{\circledR}$ CRL-2378). After viral cytopathic effect observation, virus purification was performed with caesium chloride gradient as described previously [37,38]. Virulent RVA for inoculation of cynomolgus monkeys was used at dose $3.1 \times 10^{6}$ fluorescent focus-forming units $(\mathrm{FFU}) / \mathrm{mL}$ [39].

\subsection{Experimental Design}

Seven animals (named as X9, AB7, V11, Z7, U13, T7, and AA7) were inoculated orally with $2.0 \mathrm{~mL}\left(3.1 \times 10^{6} \mathrm{FFU} / \mathrm{mL}\right)$ of RVA suspension diluted in isotonic saline solution (inoculated group), and two animals (V7 and X11) were administrated an isotonic saline solution orally and maintained as uninfected controls (placebo group). Administration was carried out in the stomach by an appropriated gavage tube. Before viral inoculation, serum and faecal samples were collected to establish individual baseline values for biochemical, virological and immunological parameters. Clinical signs of diarrhoea, vomiting, ataxia, and dehydration and body temperature were checked daily. Watery or semiliquid faeces were considered diarrhoea, and a severity scoring of diarrhoea was adopted (mild, moderate, and severe). Monkeys were considered febrile when their body temperatures were $\geq 38.5^{\circ} \mathrm{C}$. Faecal samples were collected daily from 1 to 10 days post-inoculation (dpi). To collect blood samples and check their weights, animals were anaesthetised on 1, 3, 7 and $10 \mathrm{dpi}$ as described previously [34]. On $10 \mathrm{dpi}$, all animals were euthanized by total exsanguination under deep anaesthesia according to previous experimental infection protocol [34].

\subsection{Haematological and Biochemistry Analyses}

Blood samples were drawn from the femoral vein. For haematocrit ranges and leukocyte counts, the analysis was performed by a fully automated veterinary haematology analyser, pocH-100iVDiff (Sysmex Europe GmbH, Hamburg, Germany). For different leukocyte ranges, a series of blood films were prepared and stained using May-Grünwald-Giemsa staining. Blood samples were centrifuged at $3800 \times g$ for $10 \mathrm{~min}$, and sera aliquots were collected and stored for biochemistry analysis (potassium, chloride and sodium). Analyses were performed using Vitros 250 (Ortho Clinical Diagnostics-Johnson \& Johnson, Auckland, New Zealand). Haematocrit, biochemistry, and leukocyte parameters were based on previous study with cynomolgus monkeys maintained under laboratory conditions [40]. 
However, levels from all animals were below the parameters even before inoculation, and therefore pre-inoculation levels of the animal itself were used as parameter. The non-human primates breeding colony from Fiocruz was established and has had no new genetic improvement since 1980 until now; thus, the haematology base-line values are particular. Additionally, tropical environment conditions induce different values than other colonies.

Statistical analyses were conducted using GraphPad Prism version 7.0 (GraphPad Company, San Diego, CA, USA). One-way ANOVA was used for intra group analysis, and paired Student $t$-test was used for inter groups' analyses. Differences were considered significant at $p \leq 0.05$.

\subsection{Human Group A Rotavirus Detection by Enzyme Immunoassay}

Faecal samples were collected and screened for detection of RVA by enzyme immunoassay (EIA) RIDASCREEN ${ }^{\circledR}$ Rotavirus (R-Biopharm AG, Darmstadt, Germany) following manufacturer's recommendations.

\subsection{Qualitative and Quantitative Human Group A Rotavirus RNA Detection by Molecular} Amplification Procedures

RNA was extracted from $10 \%$ of faecal suspensions and sera samples using QIAamp Viral RNA Mini Kit ${ }^{\circledR}$ (Qiagen, Valencia, CA, USA) following manufacturer's protocol. The cDNA extension was performed using High Capacity cDNA Reverse Transcription Kit ${ }^{\circledR}$ (Applied Biosystems/Life Technologies, Carlsbad, CA, USA) using recommended primers and protocol to amplify VP6 gene [41].

To confirm the virus infection, a quantitative assay was performed, and viral RNA was quantified by real time polymerase chain reaction (qPCR) with the TaqMan ${ }^{\circledR}$ Universal PCR Master Mix (Applied Biosystems/Life Technologies). The qPCR was performed using NSP3-specific primers and a TaqMan ${ }^{\circledR}$ Probe (Applied Biosystems/Life Technologies) as previously described [42], using Applied Biosystems 7500 Real-Time PCR System (Applied Biosystems, Foster City, CA, USA). Assays were run in duplicate and used a calibrated standard curve generated with serial dilutions (ranging from $10^{0}$ to $10^{7}$ ) of a plasmid clone characterized previously [43]. Samples that showed signals crossing the threshold line in both replicates until $\mathrm{Ct} \leq 40$ and presenting a characteristic sigmoidal curve were considered positives. Target copy numbers were calculated based on $\mathrm{Ct}$ values in reference to the standard curve. The number of copies per millilitre was determined by adjusting values according to volumes used for each step of the procedure (i.e., extraction, and the qRT-PCR reaction). Limit of detection for RTqPCR assay is of $4.4 \times 10^{2} \mathrm{RNA}$ copies/mg or mL [44].

\subsection{Evidence of Infectious Particles from Faeces}

Stool samples of inoculated and control animals were used to inoculate MA-104 cells to confirm RVA infectivity. One faeces sample of each animal was selected by positive RVA RNA in PCR, in different times of infection, to be used as inoculum: i.e., AB7 at 5 dpi; T7, V11 and Z7 at 7 dpi; AA7, X9, U13, V7 and X11 at 6 dpi. Cells infection was performed as described previously [39]. In brief, monolayers of cells were grown in Lab-Tek ${ }^{\circledR}$ Chamber Slide ${ }^{\mathrm{TM}}$ System (Nalgene Nunc, Naperville, IL, USA), and infection was performed with supernatant of $10 \%$ of faeces suspensions treated with trypsin to activate the virus. In order to clarify and remove bacteria, inoculum was centrifuged previously at $10,000 \times g$ for $15 \mathrm{~min}$ and filtered by a $0.45 \mu \mathrm{m}$ filter. 
Table 1. Quantification of group A rotaviruses from faeces and sera of cynomolgus monkey by reverse transcription-real time polymerase chain reaction.

\begin{tabular}{|c|c|c|c|c|c|c|c|c|c|}
\hline & \multicolumn{2}{|c|}{ Placebo Group Monkeys } & \multicolumn{7}{|c|}{ Inoculated Group Monkeys } \\
\hline & $\mathrm{X} 11$ & V7 & $\mathrm{AB} 7$ * & AA7 & Z7 & X9 & V11 & U13 & $\mathrm{T} 7$ * \\
\hline Age & 5 y $8 \mathrm{~m}$ & 6 y $10 \mathrm{~m}$ & 2 y $8 \mathrm{~m}$ & 3 y $5 \mathrm{~m}$ & 4 y $6 \mathrm{~m}$ & 5 y $9 \mathrm{~m}$ & 6 y $8 \mathrm{~m}$ & 7 y 2 m & 8 y $9 \mathrm{~m}$ \\
\hline Weight (kg) & 6.29 & 6.72 & 2.43 & 2.35 & 3.98 & 4.66 & 6.70 & 5.83 & 5.19 \\
\hline DPI & \multicolumn{9}{|c|}{ Faeces (RNA copies/mg) } \\
\hline 0 & $(-)$ & $(-)$ & $(-)$ & $(-)$ & $(-)$ & $(-)$ & $(-)$ & $(-)$ & $(-)$ \\
\hline 1 & $(-)$ & $(-)$ & $(-)$ & $(-)$ & $(-)$ & $(-)$ & $(-)$ & $6.137 \times 10^{3}$ & $5.709 \times 10^{3}$ \\
\hline 2 & $(-)$ & $(-)$ & ${ }^{t++} 3.0 \times 10^{3}$ & $5.4 \times 10^{3}$ & $5.691 \times 10^{3}$ & $(-)$ & $6.5 \times 10^{6}$ & $4.646 \times 10^{3}$ & $1.749 \times 10^{3}$ \\
\hline 3 & $(-)$ & $(-)$ & ${ }^{++\dagger}(-)$ & $1.041 \times 10^{4}$ & $5.211 \times 10^{3}$ & $3.531 \times 10^{3}$ & $3.6 \times 10^{3}$ & $4.594 \times 10^{3}$ & $8.229 \times 10^{3}$ \\
\hline 4 & $(-)$ & $(-)$ & $4.714 \times 10^{3}$ & $3.669 \times 10^{3}$ & $(-)$ & $4.269 \times 10^{3}$ & $1.068 \times 10^{4}$ & $(-)$ & $(-)$ \\
\hline 5 & $(-)$ & $(-)$ & $3.686 \times 10^{3}$ & $(-)$ & $(-)$ & $(-)$ & $(-)$ & $(-)$ & $(-)$ \\
\hline 6 & $(-)$ & $(-)$ & $3.12 \times 10^{3}$ & $1.174 \times 10^{4}$ & $4.217 \times 10^{3}$ & $2.160 \times 10^{3}$ & $9.909 \times 10^{3}$ & $8.674 \times 10^{3}$ & $4.251 \times 10^{3}$ \\
\hline 7 & $(-)$ & $(-)$ & $2.451 \times 10^{3}$ & $4.149 \times 10^{3}$ & $1.01 \times 10^{4}$ & $(-)$ & $1.239 \times 10^{4}$ & $(-)$ & ${ }^{+\dagger} 1.903 \times 10^{3}$ \\
\hline 8 & $(-)$ & $(-)$ & $(-)$ & $(-)$ & $(-)$ & $(-)$ & $(-)$ & $(-)$ & ${ }^{+\dagger}(-)$ \\
\hline 9 & $(-)$ & $(-)$ & $3.497 \times 10^{3}$ & $6.703 \times 10^{3}$ & $(-)$ & $3.36 \times 10^{3}$ & $(-)$ & $(-)$ & $+(-)$ \\
\hline 10 & $(-)$ & $(-)$ & $(-)$ & $(-)$ & $(-)$ & $(-)$ & $(-)$ & $(-)$ & $3.051 \times 10^{3}$ \\
\hline DPI & \multicolumn{9}{|c|}{ Sera (RNA copies/mL) } \\
\hline 0 & $(-)$ & $(-)$ & $(-)$ & $(-)$ & $(-)$ & $(-)$ & $(-)$ & $(-)$ & $(-)$ \\
\hline 1 & $(-)$ & $(-)$ & $(-)$ & $(-)$ & $1.455 \times 10^{3}$ & $1.589 \times 10^{3}$ & $(-)$ & $2.253 \times 10^{3}$ & $(-)$ \\
\hline 3 & $(-)$ & $(-)$ & $2.157 \times 10^{3}$ & $(-)$ & $9.549 \times 10^{2}$ & $(-)$ & $9.206 \times 10^{2}$ & $(-)$ & $(-)$ \\
\hline 7 & $(-)$ & $(-)$ & $(-)$ & $(-)$ & $(-)$ & $(-)$ & $(-)$ & $(-)$ & $(-)$ \\
\hline
\end{tabular}

DPI: Day(s) post-inoculation; (-): not detected; y: year; m: month; ${ }^{*}$ Animal which presented episodes of diarrhoea. Diarrhoea severity: ${ }^{\dagger}$ mild; ${ }^{+\dagger}$ moderate; ${ }^{+\dagger+}$ severe. Limit of detection for RTqPCR assay is of $4.4 \times 10^{2} \mathrm{RNA}$ copies $/ \mathrm{mg}$ or $\mathrm{mL}$ [44]. Animal weights at $3 \mathrm{dpi}$. 
After $18 \mathrm{~h}$ incubation of the culture, indirect immunofluorescence was performed with adaptions of a previous protocol described by Montero et al. (2008) [45]. Cells were fixed with $4 \%$ paraformaldehyde. Permeabilization was proceeded by incubation in $0.5 \%$ Triton X-100 with $1 \%$ bovine serum albumin (BSA), and blocking was carried out by incubation with $4 \%$ BSA, $0.1 \%$ tween 20. Cells were incubated with primary antibodies (MAb anti-VP6 IgG; Abcam ${ }^{\circledR}$, Cambridge, UK), followed by incubation with corresponding secondary antibody (donkey anti-mouse IgG/ Alexa Fluor ${ }^{\circledR}$ 488; Abcam ${ }^{\circledR}$, Cambridge, UK), both incubation were carried out for $30 \mathrm{~min}$ at room temperature. Slides were finished using glycerol, and then covered with glass slides. Cells were analysed using ApoTome microscope (Zeiss, Jena, Germany).

\section{Results}

Clinical signals of RVA infection, such as fever $\left(\geq 38.5^{\circ} \mathrm{C}\right)$, emesis, anorexia, and weight loss, were investigated during this study. The primary symptom of RVA infection was diarrhoea observed during the course of infection (1 to $10 \mathrm{dpi}$ ); exceptions were T7 and AB7 monkeys, which presented episodes of diarrhoea for three days (from 7 to $9 \mathrm{dpi}$ ) and two days (from 2 to $3 \mathrm{dpi}$ ), respectively. In T7, diarrhoea severity was classified as moderate on the first two days and mild at the last one. In AB7, diarrhoea was severe for two days. Analysis of biochemical parameters in the sera showed a decrease in the potassium $\left(\mathrm{K}^{+}\right)$levels from 7 to $10 \mathrm{dpi}$ in the inoculated group, but no statistical significance was observed (Figure 1a). Such as three inoculated monkeys (T7, AB7, and AA7) showed a decrease in serum $\mathrm{K}^{+}$levels from 1 to $10 \mathrm{dpi}$, which two had diarrhoea. Thus, the inoculated group was divided into animals with and without biochemical signals. According statistical analysis, at 3 and $10 \mathrm{dpi}$, the inoculated group with biochemical changes $\mathrm{K}^{+}$levels was significantly reduced in comparison with placebo group $(p<0.01)$ and inoculated group without $\mathrm{K}^{+}$decrease $(p<0.05)$ (Figure $\left.1 \mathrm{~b}\right)$. Sodium $\left(\mathrm{Na}^{+}\right)$ and chloride $\left(\mathrm{Cl}^{-}\right)$levels as well as specific haematological counts did not change in the inoculated group. An elevation in the lymphocyte count was observed in one animal, AB7, from 7 dpi onwards $\left(5.6 \times 10^{3} / \mathrm{mL}\right)$.

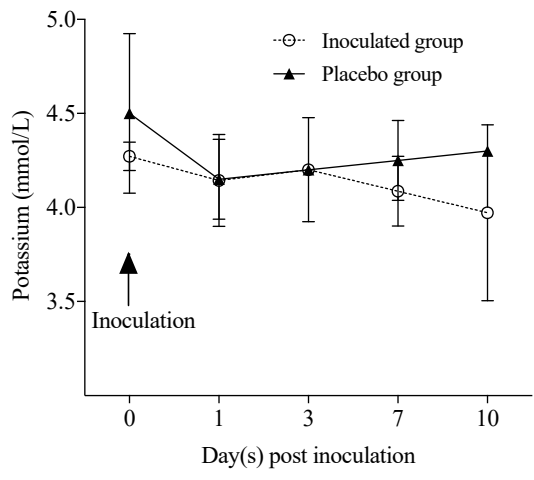

(a)

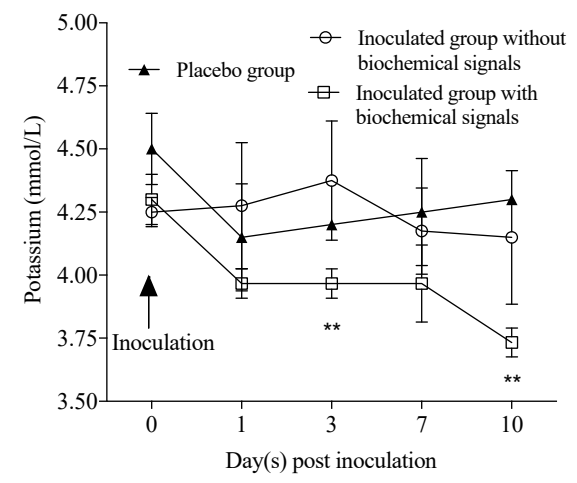

(b)

Figure 1. Sera potassium levels of cynomolgus monkeys. (a) Differences between the inoculated group and the placebo group. The arrow represents the inoculation time; (b) Comparison among the inoculated group without biochemical signals (Z7, V11, X9 and U13); inoculated group with biochemical signal (potassium decrease-T7, AB7 and AA7); and placebo group (V7 and X11). The arrow represents inoculation time. ${ }^{* *}$ Statistical analyses between groups presented significance in reducing of $\mathrm{K}^{+}$levels at 3 and $10 \mathrm{dpi}(p<0.01)$.

The RVA replication in the enterocytes of cynomolgus monkeys occurred through intermittent viral RNA detection in the faeces and a short-term detection of RVA RNA in the serum (Table 1). Monkeys' weight shown in Table 1 was measured at 3 dpi, and no significant difference of weight loss was observed from the first until the last day. Besides the detection of infectious particles in the faeces of all infected monkeys, there was also demonstrated viral replication in MA-104 cells. Specific 
fluorescence was only visible in the cytoplasm of infected cells, showing a granular fluorescence pattern as presented in Figure 2. These findings were not necessarily accompanied by episodes of diarrhoea. Three animals, Z7, T7 and AA7, were considered febrile, presenting temperatures of $38.6^{\circ} \mathrm{C}$ (7 dpi), $38.5^{\circ} \mathrm{C}(1 \mathrm{dpi})$, and $39.0^{\circ} \mathrm{C}(1 \mathrm{dpi})$, respectively. No other animal had fever episodes during the whole experiment. In control animals, the average temperature presented was $36.9{ }^{\circ} \mathrm{C}$.

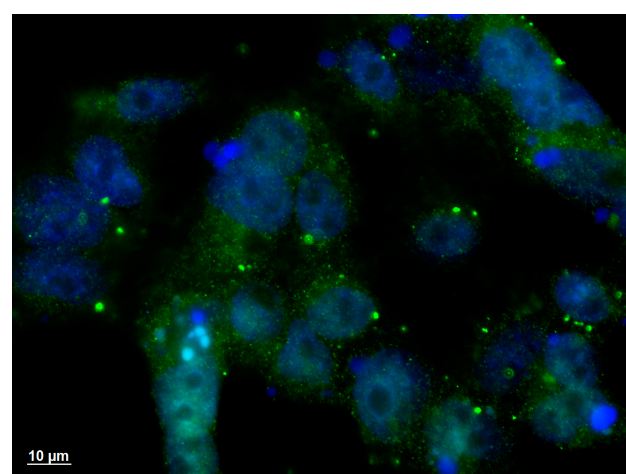

(a)

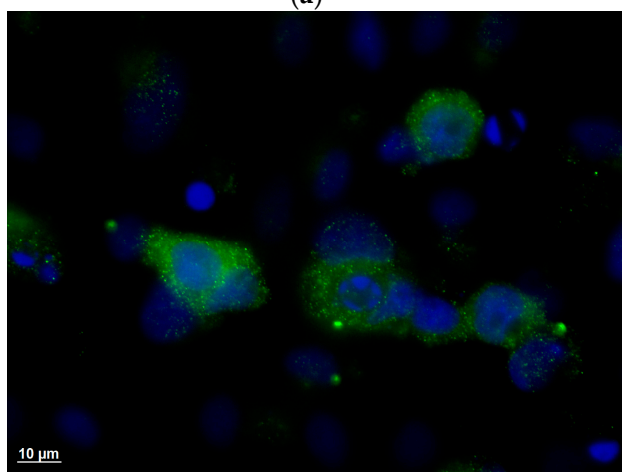

(c)

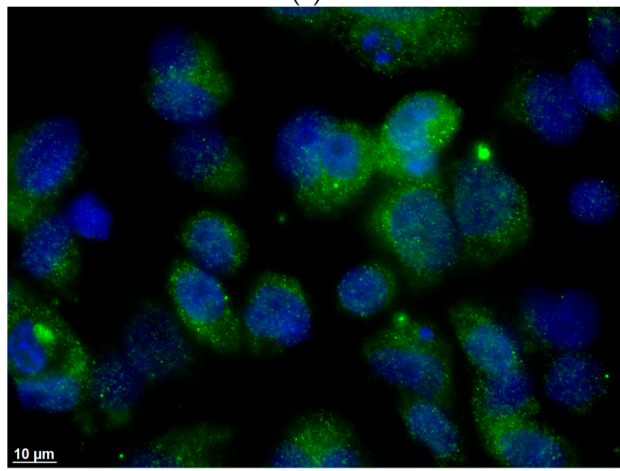

(e)

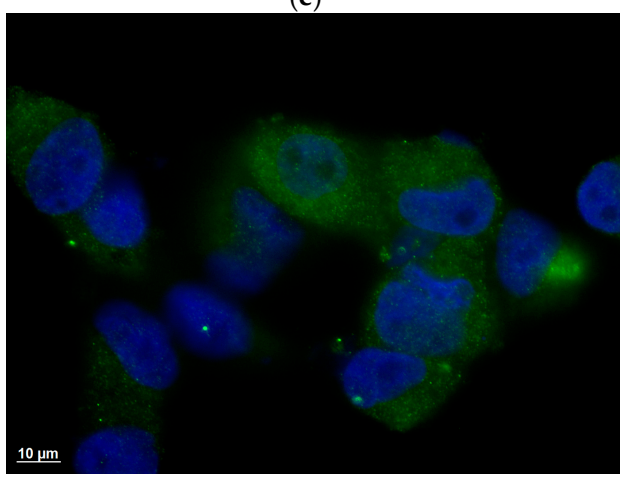

(g)

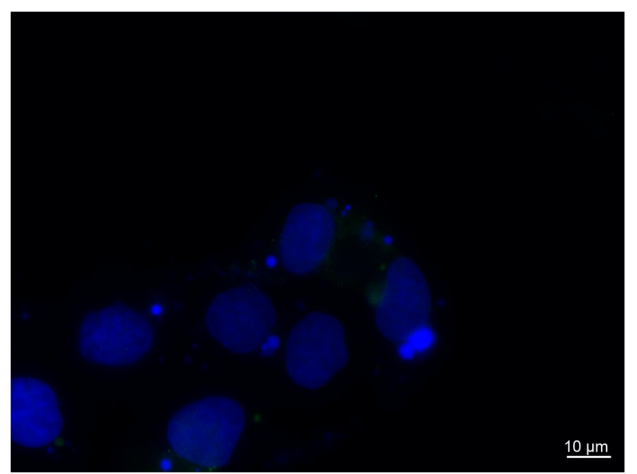

(b)

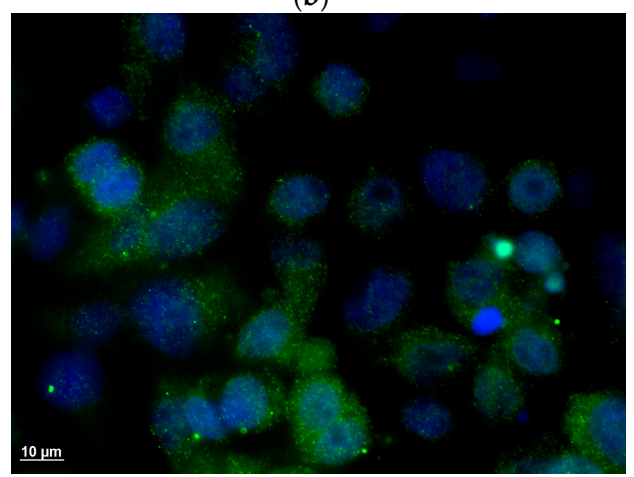

(d)

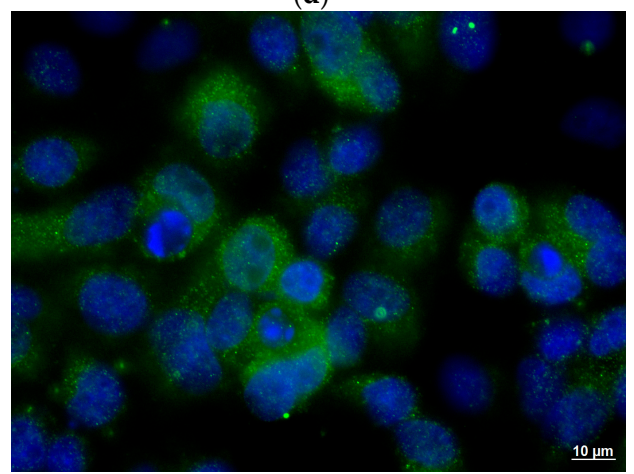

(f)

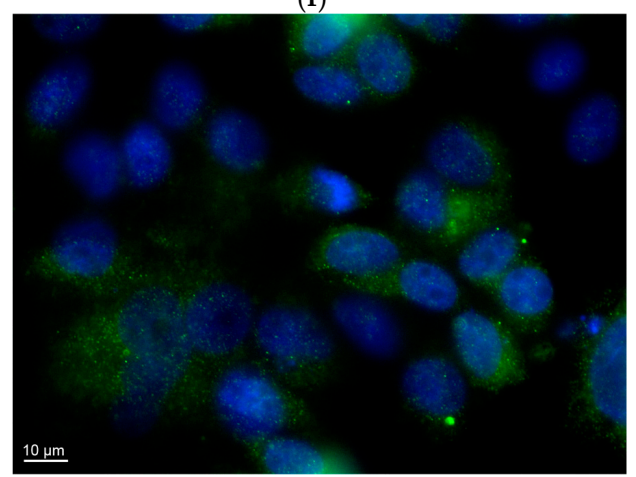

(h)

Figure 2. Cont. 


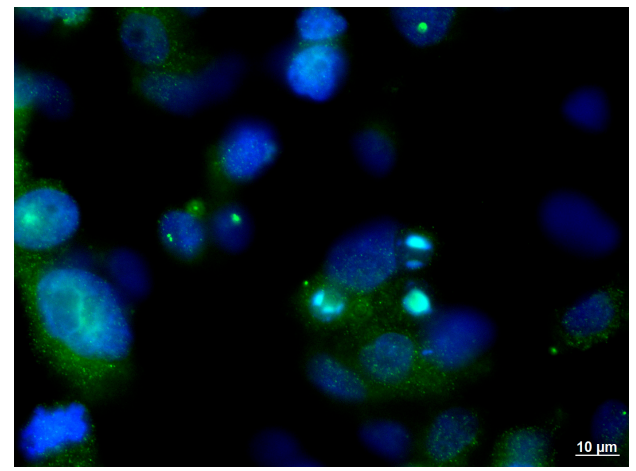

(i)

Figure 2. Indirect immunofluorescence of MA-104 cell culture infected with Wa rotavirus (RVA) of inoculum and monkeys' faeces, showing rotavirus infection pattern with granular and cytoplasmatic fluorescence in cell monolayer. (a) RVA inoculum administrated in monkeys $\left(3.1 \times 10^{6} \mathrm{FFU} / \mathrm{mL}\right)$. (b) V7 monkey faeces at 6 dpi (control monkey). (c) T7 monkey faeces at 7 dpi. (d) U13 monkey faeces at $6 \mathrm{dpi}$. (e) $\mathrm{Z7}$ monkey faeces at $7 \mathrm{dpi}$. (f) $\mathrm{X} 9$ monkey faeces at $6 \mathrm{dpi}$. (g) AA7 monkey faeces at 6 dpi. (h) AB7 monkey faeces at 5 dpi. (i) V11 monkey faeces at 7 dpi. Wa RVA antigen (VP6) was stained in green (Alexa Fluor ${ }^{\circledR} 488 \mathrm{~nm}$ ) and nucleus were stained in blue with DAPI (4',6-diamidino-2-phenylindole).

All inoculated monkeys in the inoculated group showed the elimination of RVA in faeces. The RVA shedding in faecal samples showed an intermittent pattern of viral elimination. The first viral RNA detection occurred between 1 and 3 dpi and persisted from 7 to $10 \mathrm{dpi}$ (Table 1). Monkeys in the inoculated group showed an interval of one to two days without RVA RNA detectable in their stool samples; five of them (AB7, T7, X9, AA7 and Z7) had this interval twice (Table 1). During the course of viral infection, the animals presented an average of $10^{3} \mathrm{RNA}$ copies/mg in their faeces. The presence of infectious viral particles in faecal samples at different days post RVA inoculation occurred independently if monkeys presented diarrhoeal episodes or not (Figure 2). No evidence of infectious particles was detected in the faeces of the two control animals. Viral RNA in serum was detected in five out of seven animals from the inoculated group on either 1 or $3 \mathrm{dpi}$ and occurred for only one day in four monkeys; the exception was Z7, for which viral RNA was detected on both days (Table 1). All samples were negative for RVA by EIA.

\section{Discussion}

In this study, we reproduced an infection with heterologous RVA in cynomolgus monkeys. Human RVA is an important causative agent of AG and death in children under 5 years of age [1]. Human RVA-induced AG was accompanied by virus shedding in juvenile (AB7-2 years and 8 months) and adult (T7-8 years and 9 months) monkeys. Most of the inoculated animals developed oligosymptomatic infection, which corroborates a previous report showing an effective Wa RVA infection in 4/6 inoculated new-born monkeys, with one presenting diarrhoea [24]. Leong et al. [25] showed a dose-dependent pattern of RVA infection and AG in new-born cynomolgus monkeys ( $24 \mathrm{~h}$ old). The new-born susceptibility to human RVA was also described in rhesus macaques, vervet monkeys and baboons $[23,26]$. Even infected new-born rhesus monkeys with homologous wild-type RVA may not show signs of diarrhoea or dehydration and remain clinically normal despite shedding large amounts of RVA in their faeces [46].

In our study, RVA detection was assessed in faeces during the whole period, whereas in the placebo group all samples were negative. The first viral RNA detection in each animal occurred at 1,2 or 3 dpi. After a one- or two-day interval without viral shedding, a second detection was observed, occurring either on 4 or 6 dpi. Thus, the first period of viral excretion most likely represents part of the inoculum (RVA incubation period after oral inoculation) being naturally shedding, whereas the second wave 
of viral shedding observed (second detection) is likely indicative of the replication. Comparatively, after the incubation period, monkey AB7 showed continuous viral shedding (5 days), whereas monkey U13 shed for just 1 day. Similarities in this profile were observed in human volunteers, with RVA induced-illness occurring 2-6 days after viral ingestion and continuing for 1-4 days, as reviewed by others [47]. Rotavirus shedding continued for up to 10 days after viral ingestion in humans [48]. All RVA inoculated monkeys presented an intermittence in rotavirus shedding, interestingly four monkeys (AB7, AA7, X9, and T7) showed a third detection period. In our opinion this last period detection proves rotavirus replication. This intermittent rotavirus shedding occurs in both symptomatic and asymptomatic children [49]. Despite detection of rotavirus RNA in faeces, the viral load was not elevated, with an average of $10^{3}$ copies of RNA $/ \mathrm{mg}$, and the highest quantification was of $10^{4}$ copies of RNA/mg. Adults eliminate less rotavirus in faeces than children [50].

We detected viral RNA in sera from 5/7 inoculated animals. Control animals were negative for WA RVA RNA during the whole period of study. This detection was transient (one or two days in the majority of inoculated animals). Comparatively, RVA antigen and RNA were also detected in sera of 50 to $90 \%$ of children with RVA infections [51-55]. Despite reduced clinical relevance in our study, the presence of viral RNA in the blood stream represents the capacity of the virus to pass through the intestinal barrier, confirming virulence of human RVA in cynomolgus monkeys. Additionally, detectable RVA viraemia may contribute to the extraintestinal spread of the virus during the intestinal infection phase [31,51,52,56-59]. RVA most likely escapes the intestinal tract in children and accesses the bloodstream through M cells, which overlie Peyer's patches [51]. Although monkey T7 presented expressive AG, it did not develop viraemia, indicating that AG may not be the critical determinant of antigenaemia or viraemia [52,60].

EIA failed to detect RVA antigens in sera or faeces of RVA-inoculated cynomolgus monkeys, confirming other previous and inconclusive studies about juvenile and adult non-human primate susceptibility $[24,25]$. Recently, more sensitive molecular methodologies have improved human RVA diagnosis [61,62]; thus, we confirmed positive results by RT-PCR and qPCR [63]. The commercial antigen-based-test (EIA) has a minimum limit of detection of $10^{6}$ viral particles [64]. Other authors reported that symptom-free adult monkeys can shed RVA in quantities so low as to be undetectable by most routine assays [65]. In our opinion, a reduced viral load observed in cynomolgus host justified the absence of RVA antigen detection in this model, as observed in other heterologous infections [32,34]. In order to confirm that the virus detected in faeces was not merely free RNA, but the complete infectious particles (virion), the infection of MA-104 cells with faecal samples was performed. The presence of infectious particles in faeces was confirmed in seven inoculated animals. Faecal samples corresponded to 5, 6 and 7 days post inoculation, the second period of viral shedding in faeces, probably the product of RVA replication in enterocytes of inoculated cynomolgus monkeys.

The finding of progressive low serum concentration of $\mathrm{K}^{+}$detected in T7, AB7 and AA7 from 1 dpi onwards was coincident with episodes of diarrhoea diagnosed in two of these animals during experimental infection, and similar findings were described by other authors [66,67]. Commonly, diarrhoea pathogeny includes water and nutrient absorption reductions with an elevation of intestinal fluid secretion, consequently resulting in electrolyte and water loss [68]. However, no changes were observed in $\mathrm{Na}^{+}$and $\mathrm{Cl}^{-}$levels and dehydration signs in our animal model; this clinical pattern may be also observed in children with gastroenteritis [69,70]. In general, RVA AG infection is characterized as an inflammatory intestinal disease localized in the upper intestinal tract, without demonstration of severe systemic effects [71]. Detected viraemia observed in our study was not associated with diarrhoea severity and/or biochemical blood changes in RVA infection. Elevation of lymphocyte counts was the other haematological change identified in AB7 from 7 to $10 \mathrm{dpi}$; a short-term T cell elevation has also been described in human rotavirus infection in gnotobiotic pigs [72]. Viral infections were associated with increase of lymphocytes levels, and this was also observed for rotavirus [73]; however, in our study, lymphocyte variation was insignificant. Although viral infection has developed an oligosymptomatic gastroenteritis pattern in some animals, the decision to use a heterologous rotavirus 
in the establishment of an experimental infection model is justified by the further model test of human vaccines and immunotherapies. A future immunotherapy could benefit especially hospitalized adult patients and immunocompromised adults with severe clinical conditions with rotavirus gastroenteritis.

\section{Conclusions}

Taken together, these results confirm that cynomolgus monkeys in different ages developed heterologous infections with human RVA. In general, cynomolgus monkeys developed oligosymptomatic pattern of infection, with episodes of AG that may have induced electrolytic disturbances with detectable RVA RNA in sera and low-titered viral shedding, but infectious, in their faeces. Other genotypes of rotavirus have emerged as a form of escape of the host immune system, thus, vaccines need to be reformulated with new genotypes. Hence, cynomolgus monkeys may represent a promising model to evaluate new candidates for human RVA vaccines, efficacy of new antiviral therapies, and studies about pathogenesis of human RVA infection.

Author Contributions: G.A.B., E.d.M.V., J.P., J.P.L. and M.A.P. conceived and designed the experiments; G.A.B., J.R.G., E.d.M.V., A.M.F., N.R.G., N.M.L., A.d.S.d.S. and M.A.P. performed the experiments; G.A.B., J.P.L. and M.A.P. analyzed the data; A.M.F., C.H. and A.C.G. contributed reagents/materials/analysis tools; G.A.B., J.P.L. and M.A.P. wrote the paper.

Acknowledgments: We would like to thank the staffs of the Centro de Experimentação em Primatas não-Humanos (Instituto Oswaldo Cruz/Fiocruz), the Laboratório de Análises Clínicas de Animais de Laboratório (Rede de Plataforma Tecnológicas/Fiocruz), the Laboratório de Ultraestrutura Celular (Instituto Oswaldo Cruz/Fiocruz), and the Instituto de Ciência e Tecnologia em Biomodelos (ICTB/Fiocruz). The authors also thank Tulio Machado Fumian, Marcia Terezinha Baroni de Moraes e Souza and Márcia Maria Araújo Pimenta of Laboratório de Virologia Comparada e Ambiental for help in laboratory procedures. This work was supported by National Council for Scientific and Technological Development (CNPq-MCT/CNPq No 14/2010-Universal-Grant number 479965/2010-2); the Carlos Chagas Filho Foundation for Research Support of Rio de Janeiro State (FAPERJ-APQ1 2010/02-Grant number E-26/110.517/2011); and Oswaldo Cruz Institute (LDTV-POM-IOC/Fiocruz).

Conflicts of Interest: The authors declare no conflict of interest.

\section{References}

1. Madsen, L.B.; Ustrup, M.; Hansen, K.S.; Nyasulu, P.S.; Bygbjerg, I.C.; Konradsen, F. Estimating the costs of implementing the rotavirus vaccine in the national immunisation programme: The case of Malawi. Trop. Med. Int. Health 2014, 19, 177-185. [CrossRef] [PubMed]

2. Rotavirus vaccines: WHO position paper-January 2013. Wkly. Epidemiol. Rec. 2013, 88, 49-64.

3. Parashar, U.D.; Nelson, E.A.S.; Kang, G. Diagnosis, management, and prevention of rotavirus gastroenteritis in children. BMJ 2013, 347, f7204. [CrossRef] [PubMed]

4. Patel, M.M.; Glass, R.; Desai, R.; Tate, J.E.; Parashar, U.D. Fulfilling the promise of rotavirus vaccines: How far have we come since licensure? Lancet Infect. Dis. 2012, 12, 561-570. [CrossRef]

5. Velázquez, F.R.; Matson, D.O.; Calva, J.J.; Guerrero, L.; Morrow, A.L.; Carter-Campbell, S.; Glass, R.I.; Estes, M.K.; Pickering, L.K.; Ruiz-Palacios, G.M. Rotavirus infection in infants as protection against subsequent infections. N. Engl. J. Med. 1996, 335, 1022-1028. [CrossRef] [PubMed]

6. Jiang, B.; Gentsch, J.R.; Glass, R.I. The role of serum antibodies in the protection against rotavirus disease: An overview. Clin. Infect. Dis. 2002, 34, 1351-1361. [CrossRef] [PubMed]

7. Snodgrass, D.R.; Wells, P.W. Passive immunity in rotaviral infections. J. Am. Vet. Med. Assoc. 1978, 173, 565-568. [PubMed]

8. Fernandez, F.M.; Conner, M.E.; Hodgins, D.C.; Parwani, A.V.; Nielsen, P.R.; Crawford, S.E.; Estes, M.K.; Saif, L.J. Passive immunity to bovine rotavirus in newborn calves fed colostrum supplements from cows immunized with recombinant SA11 rotavirus core-like particle (CLP) or virus-like particle (VLP) vaccines. Vaccine 1998, 16, 507-516. [CrossRef]

9. Yuan, L.; Iosef, C.; Azevedo, M.S.; Kim, Y.; Qian, Y.; Geyer, A.; Nguyen, T.V.; Chang, K.O.; Saif, L.J. Protective immunity and antibody-secreting cell responses elicited by combined oral attenuated Wa human rotavirus and intranasal Wa 2/6-VLPs with mutant Escherichia coli heat-labile toxin in gnotobiotic pigs. J. Virol. 2001, 75, 9229-9238. [CrossRef] [PubMed] 
10. Azevedo, M.S.; Yuan, L.; Jeong, K.-I.; Gonzalez, A.; Nguyen, T.V.; Pouly, S.; Gochnauer, M.; Zhang, W.; Azevedo, A.; Saif, L.J. Viremia and nasal and rectal shedding of rotavirus in gnotobiotic pigs inoculated with Wa human rotavirus. J. Virol. 2005, 79, 5428-5436. [CrossRef] [PubMed]

11. Wen, K.; Li, G.; Zhang, W.; Azevedo, M.S.P.; Saif, L.J.; Liu, F.; Bui, T.; Yousef, A.; Yuan, L. Development of $\gamma \delta$ $\mathrm{T}$ cell subset responses in gnotobiotic pigs infected with human rotaviruses and colonized with probiotic lactobacilli. Vet. Immunol. Immunopathol. 2011, 141, 267-275. [CrossRef] [PubMed]

12. Ciarlet, M.; Crawford, S.E.; Barone, C.; Bertolotti-Ciarlet, A.; Ramig, R.F.; Estes, M.K.; Conner, M.E. Subunit rotavirus vaccine administered parenterally to rabbits induces active protective immunity. J. Virol. 1998, 72, 9233-9246. [PubMed]

13. Preidis, G.A.; Saulnier, D.M.; Blutt, S.E.; Mistretta, T.-A.; Riehle, K.P.; Major, A.M.; Venable, S.F.; Barrish, J.P.; Finegold, M.J.; Petrosino, J.F.; et al. Host response to probiotics determined by nutritional status of rotavirus-infected neonatal mice. J. Pediatr. Gastroenterol. Nutr. 2012, 55, 299-307. [CrossRef] [PubMed]

14. Ciarlet, M.; Conner, M.E.; Finegold, M.J.; Estes, M.K. Group a rotavirus infection and age-dependent diarrheal disease in rats: A new animal model to study the pathophysiology of rotavirus infection. J. Virol. 2002, 76, 41-57. [CrossRef] [PubMed]

15. Ramani, S.; Crawford, S.E.; Blutt, S.E.; Estes, M.K. Human organoid cultures: Transformative new tools for human virus studies. Curr. Opin. Virol. 2018, 29, 79-86. [CrossRef] [PubMed]

16. Chege, G.K.; Snodgrass, D.R.; Campbell, I.; Hart, C.; Omollo, E.; Mwenda, J.M. Prevalence of rotavirus antibodies in a non-human primate colony. Afr. J. Health Sci. 1995, 2, 296-299. [PubMed]

17. Otsyula, M.; Yee, J.; Suleman, M.; Tarara, R.; Martins, J.; Woods, P.; Glass, R.; Jennings, M. Rotavirus infection in African, non-human primates. Ann. Trop. Med. Parasitol. 1996, 90, 659-661. [CrossRef] [PubMed]

18. Kojima, K.; Taniguchi, K.; Kobayashi, N. Species-specific and interspecies relatedness of NSP1 sequences in human, porcine, bovine, feline, and equine rotavirus strains. Arch. Virol. 1996, 141, 1-12. [CrossRef] [PubMed]

19. El-Attar, L.; Dhaliwal, W.; Howard, C.R.; Bridger, J.C. Rotavirus cross-species pathogenicity: Molecular characterization of a bovine rotavirus pathogenic for pigs. Virology 2001, 291, 172-182. [CrossRef] [PubMed]

20. Kumar, N.; Malik, Y.S.; Sharma, K.; Dhama, K.; Ghosh, S.; Bányai, K.; Kobayashi, N.; Singh, R.K. Molecular characterization of unusual bovine rotavirus A strains having high genetic relatedness with human rotavirus: Evidence for zooanthroponotic transmission. Zoonoses Public Health 2018. [CrossRef] [PubMed]

21. Nakagomi, O.; Nakagomi, T. Interspecies transmission of rotaviruses studied from the perspective of genogroup. Microbiol. Immunol. 1993, 37, 337-348. [CrossRef] [PubMed]

22. Iturriza Gómara, M.; Kang, G.; Mammen, A.; Jana, A.K.; Abraham, M.; Desselberger, U.; Brown, D.; Gray, J. Characterization of G10P[11] rotaviruses causing acute gastroenteritis in neonates and infants in Vellore, India. J. Clin. Microbiol. 2004, 42, 2541-2547. [CrossRef] [PubMed]

23. Wyatt, R.G.; Sly, D.L.; London, W.T.; Palmer, A.E.; Kalica, A.R.; Van Kirk, D.H.; Chanock, R.M.; Kapikian, A.Z. Induction of diarrhea in colostrum-deprived newborn rhesus monkeys with the human reovirus-like agent of infantile gastroenteritis. Arch. Virol. 1976, 50, 17-27. [CrossRef] [PubMed]

24. Majer, M.; Behrens, F.; Weinmann, E.; Mauler, R.; Maass, G.; Baumeister, H.G.; Luthardt, T. Diarrhea in newborn cynomologus monkeys infected with human rotavirus. Infection 1978, 6, 71-72. [CrossRef] [PubMed]

25. Leong, Y.K.; Awang, A. Experimental group A rotaviral infection in cynomolgus monkeys raised on formula diet. Microbiol. Immunol. 1990, 34, 153-162. [CrossRef] [PubMed]

26. Chege, G.K.; Steele, A.D.; Hart, C.A.; Snodgrass, D.R.; Omolo, E.O.; Mwenda, J.M. Experimental infection of non-human primates with a human rotavirus isolate. Vaccine 2005, 23, 1522-1528. [CrossRef] [PubMed]

27. Nayak, M.K.; De, P.; Manna, B.; Dutta, S.; Bhadra, U.K.; Chawla-Sarkar, M. Species A rotaviruses isolated from hospitalized patients over 5 years of age in Kolkata, India, in 2012/13. Arch. Virol. 2018, 163, 745-750. [CrossRef] [PubMed]

28. Bruijning-Verhagen, P.; Nipshagen, M.D.; de Graaf, H.; Bonten, M.J.M. Rotavirus disease course among immunocompromised patients; 5-year observations from a tertiary care medical centre. J. Infect. 2017, 75, 448-454. [CrossRef] [PubMed]

29. Raini, S.K.; Nyangao, J.; Kombich, J.; Sang, C.; Gikonyo, J.; Ongus, J.R.; Odari, E.O. Human rotavirus group a serotypes causing gastroenteritis in children less than 5 years and HIV-infected adults in Viwandani slum, Nairobi. Ethiop. J. Health Sci. 2015, 25, 39-46. [CrossRef] [PubMed] 
30. Saulsbury, F.T.; Winkelstein, J.A.; Yolken, R.H. Chronic rotavirus infection in immunodeficiency. J. Pediatr. 1980, 97, 61-65. [CrossRef]

31. Glass, R.I.; Parashar, U.; Patel, M.; Gentsch, J.; Jiang, B. Rotavirus vaccines: Successes and challenges. J. Infect. 2014, 68 (Suppl. S1), S9-S18. [CrossRef] [PubMed]

32. Amado, L.A.; Marchevsky, R.S.; de Paula, V.S.; Hooper, C.; Freire, M.D.S.; Gaspar, A.M.C.; Pinto, M.A. Experimental hepatitis A virus (HAV) infection in cynomolgus monkeys (Macaca fascicularis): Evidence of active extrahepatic site of HAV replication. Int. J. Exp. Pathol. 2010, 91, 87-97. [CrossRef] [PubMed]

33. Andrade, M.R.; Yee, J.; Barry, P.; Spinner, A.; Roberts, J.A.; Cabello, P.H.; Leite, J.P.; Lerche, N.W. Prevalence of antibodies to selected viruses in a long-term closed breeding colony of rhesus macaques (Macaca mulatta) in Brazil. Am. J. Primatol. 2003, 59, 123-128. [CrossRef] [PubMed]

34. De Carvalho, L.G.; Marchevsky, R.S.; dos Santos, D.R.L.; de Oliveira, J.M.; de Paula, V.S.; Lopes, L.M.; Van der Poel, W.H.M.; González, J.E.; Munné, M.S.; Moran, J.; et al. Infection by Brazilian and Dutch swine hepatitis E virus strains induces haematological changes in Macaca fascicularis. BMC Infect. Dis. 2013, 13, 495. [CrossRef] [PubMed]

35. Gardinali, N.R.; Guimarães, J.R.; Melgaço, J.G.; Kevorkian, Y.B.; de Oliveira Bottino, F.; Vieira, Y.R.; da Silva, A.C.; Pinto, D.P.; da Fonseca, L.B.; Vilhena, L.S.; et al. Cynomolgus monkeys are successfully and persistently infected with hepatitis E virus genotype 3 (HEV-3) after long-term immunosuppressive therapy. PLoS ONE 2017, 12, e0174070. [CrossRef] [PubMed]

36. Leon, L.A.; Marchevsky, R.S.; Gaspar, A.M.; Garcia, R.D.; Almeida, A.J.; Pelajo-Machado, M.; Castro, T.X.; Nascimento, J.P.; Brown, K.E.; Pinto, M.A. Cynomolgus monkeys (Macaca fascicularis) experimentally infected with B19V and hepatitis A virus: No evidence of the co-infection as a cause of acute liver failure. Mem. Inst. Oswaldo Cruz 2016, 111, 258-266. [CrossRef] [PubMed]

37. Espejo, R.T.; López, S.; Arias, C. Structural polypeptides of simian rotavirus SA11 and the effect of trypsin. J. Virol. 1981, 37, 156-160. [PubMed]

38. Zárate, S.; Espinosa, R.; Romero, P.; Méndez, E.; Arias, C.F.; López, S. The VP5 domain of VP4 can mediate attachment of rotaviruses to cells. J. Virol. 2000, 74, 593-599. [CrossRef] [PubMed]

39. Arnold, M.; Patton, J.T.; McDonald, S.M. Culturing, storage, and quantification of rotaviruses. Curr. Protoc. Microbiol. 2009. [CrossRef]

40. Rosso, M.C.; Badino, P.; Ferrero, G.; Costa, R.; Cordero, F.; Steidler, S. Biologic Data of Cynomolgus Monkeys Maintained under Laboratory Conditions. PLoS ONE 2016, 11, e0157003. [CrossRef] [PubMed]

41. Iturriza Gómara, M.; Wong, C.; Blome, S.; Desselberger, U.; Gray, J. Molecular characterization of VP6 genes of human rotavirus isolates: Correlation of genogroups with subgroups and evidence of independent segregation. J. Virol. 2002, 76, 6596-6601. [CrossRef] [PubMed]

42. Zeng, S.Q.; Halkosalo, A.; Salminen, M.; Szakal, E.D.; Puustinen, L.; Vesikari, T. One-step quantitative RT-PCR for the detection of rotavirus in acute gastroenteritis. J. Virol. Methods 2008, 153, 238-240. [CrossRef] [PubMed]

43. Fumian, T.M.; Victoria, M.; Vieira, C.B.; Fioretti, J.M.; Rocha, M.S.; Prado, T.; Guimarães, F.R.; da Gama, N.P.; de Oliveira, J.M.; Mendes, A.C.O.; et al. Enteric viruses' dissemination in a private reserve of natural heritage. Lett. Appl. Microbiol. 2018, 66, 313-320. [CrossRef] [PubMed]

44. Freeman, M.M.; Kerin, T.; Hull, J.; McCaustland, K.; Gentsch, J. Enhancement of detection and quantification of rotavirus in stool using a modified real-time RT-PCR assay. J. Med. Virol. 2008, 80, 1489-1496. [CrossRef] [PubMed]

45. Montero, H.; Rojas, M.; Arias, C.F.; López, S. Rotavirus infection induces the phosphorylation of eIF2 $\alpha$ but prevents the formation of stress granules. J. Virol. 2008, 82, 1496-1504. [CrossRef] [PubMed]

46. McNeal, M.M.; Sestak, K.; Choi, A.H.-C.; Basu, M.; Cole, M.J.; Aye, P.P.; Bohm, R.P.; Ward, R.L. Development of a rotavirus-shedding model in rhesus macaques, using a homologous wild-type rotavirus of a new $\mathrm{P}$ genotype. J. Virol. 2005, 79, 944-954. [CrossRef] [PubMed]

47. Anderson, E.J.; Weber, S.G. Rotavirus infection in adults. Lancet Infect. Dis. 2004, 4, 91-99. [CrossRef]

48. Pickering, L.K.; Bartlett, A.V.; Reves, R.R.; Morrow, A. Asymptomatic excretion of rotavirus before and after rotavirus diarrhea in children in day care centers. J. Pediatr. 1988, 112, 361-365. [CrossRef] 
49. Mukhopadhya, I.; Sarkar, R.; Menon, V.K.; Babji, S.; Paul, A.; Rajendran, P.; Sowmyanarayanan, T.V.; Moses, P.D.; Iturriza-Gomara, M.; Gray, J.J.; et al. Rotavirus shedding in symptomatic and asymptomatic children using reverse transcription-quantitative PCR. J. Med. Virol. 2013, 85, 1661-1668. [CrossRef] [PubMed]

50. Vollet, J.J.; Ericsson, C.D.; Gibson, G.; Pickering, L.K.; DuPont, H.L.; Kohl, S.; Conklin, R.H. Human rotavirus in an adult population with travelers' diarrhea and its relationship to the location of food consumption. J. Med. Virol. 1979, 4, 81-87. [CrossRef] [PubMed]

51. Blutt, S.E.; Kirkwood, C.D.; Parreño, V.; Warfield, K.L.; Ciarlet, M.; Estes, M.K.; Bok, K.; Bishop, R.F.; Conner, M.E. Rotavirus antigenaemia and viraemia: A common event? Lancet Lond. Engl. 2003, 362, 1445-1449. [CrossRef]

52. Blutt, S.E.; Matson, D.O.; Crawford, S.E.; Staat, M.A.; Azimi, P.; Bennett, B.L.; Piedra, P.A.; Conner, M.E. Rotavirus antigenemia in children is associated with viremia. PLoS Med. 2007, 4, e121. [CrossRef] [PubMed]

53. Fujita, Y.; Liu, B.; Kohira, R.; Fuchigami, T.; Mugishima, H.; Izumi, H.; Kuzuya, M.; Fujii, R.; Hamano, M.; Ogura, H. Rotavirus antigenemia and genomia in children with rotavirus gastroenteritis. Jpn. J. Infect. Dis. 2010, 63, 83-86. [PubMed]

54. Ahmed, K.; Bozdayi, G.; Mitui, M.T.; Ahmed, S.; Kabir, L.; Buket, D.; Bostanci, I.; Nishizono, A. Circulating rotaviral RNA in children with rotavirus antigenemia. J. Negat. Results Biomed. 2013, 12, 5. [CrossRef] [PubMed]

55. Hemming, M.; Huhti, L.; Räsänen, S.; Salminen, M.; Vesikari, T. Rotavirus antigenemia in children is associated with more severe clinical manifestations of acute gastroenteritis. Pediatr. Infect. Dis. J. 2014, 33, 366-371. [CrossRef] [PubMed]

56. Gilger, M.A.; Matson, D.O.; Conner, M.E.; Rosenblatt, H.M.; Finegold, M.J.; Estes, M.K. Extraintestinal rotavirus infections in children with immunodeficiency. J. Pediatr. 1992, 120, 912-917. [CrossRef]

57. Nishimura, S.; Ushijima, H.; Nishimura, S.; Shiraishi, H.; Kanazawa, C.; Abe, T.; Kaneko, K.; Fukuyama, Y. Detection of rotavirus in cerebrospinal fluid and blood of patients with convulsions and gastroenteritis by means of the reverse transcription polymerase chain reaction. Brain Dev. 1993, 15, 457-459. [CrossRef]

58. Ushijima, H.; Xin, K.Q.; Nishimura, S.; Morikawa, S.; Abe, T. Detection and sequencing of rotavirus VP7 gene from human materials (stools, sera, cerebrospinal fluids, and throat swabs) by reverse transcription and PCR. J. Clin. Microbiol. 1994, 32, 2893-2897. [PubMed]

59. Morrison, C.; Gilson, T.; Nuovo, G.J. Histologic distribution of fatal rotaviral infection: An immunohistochemical and reverse transcriptase in situ polymerase chain reaction analysis. Hum. Pathol. 2001, 32, 216-221. [CrossRef] [PubMed]

60. Ray, P.; Fenaux, M.; Sharma, S.; Malik, J.; Subodh, S.; Bhatnagar, S.; Greenberg, H.; Glass, R.I.; Gentsch, J.; Bhan, M.K. Quantitative evaluation of rotaviral antigenemia in children with acute rotaviral diarrhea. J. Infect. Dis. 2006, 194, 588-593. [CrossRef] [PubMed]

61. Dung, T.T.N.; Phat, V.V.; Nga, T.V.T.; My, P.V.T.; Duy, P.T.; Campbell, J.I.; Thuy, C.T.; Hoang, N.V.M.; Van Minh, P.; Le Phuc, H.; et al. The validation and utility of a quantitative one-step multiplex RT real-time PCR targeting rotavirus A and norovirus. J. Virol. Methods 2013, 187, 138-143. [CrossRef] [PubMed]

62. Guo, Y.-Q.; Li, D.-D.; Duan, Z.-J. Research progress of real-time quantitative PCR method for group A rotavirus detection. Bing Xue Bao Chin. J. Virol. 2013, 29, 651-654.

63. Gautam, R.; Lyde, F.; Esona, M.D.; Quaye, O.; Bowen, M.D. Comparison of Premier ${ }^{\mathrm{TM}}$ Rotaclone $^{\circledR}$, ProSpecT $^{\mathrm{TM}}$, and RIDASCREEN ${ }^{\circledR}$ rotavirus enzyme immunoassay kits for detection of rotavirus antigen in stool specimens. J. Clin. Virol. 2013, 58, 292-294. [CrossRef] [PubMed]

64. Wilde, J.; Yolken, R.; Willoughby, R.; Eiden, J. Improved detection of rotavirus shedding by polymerase chain reaction. Lancet Lond. Engl. 1991, 337, 323-326. [CrossRef]

65. Barnes, G.L.; Callaghan, S.L.; Kirkwood, C.D.; Bogdanovic-Sakran, N.; Johnston, L.J.; Bishop, R.F. Excretion of serotype G1 rotavirus strains by asymptomatic staff: A possible source of nosocomial infection. J. Pediatr. 2003, 142, 722-725. [CrossRef] [PubMed]

66. Del Castillo, J.R.; Ludert, J.E.; Sanchez, A.; Ruiz, M.C.; Michelangeli, F.; Liprandi, F. Rotavirus infection alters $\mathrm{Na}^{+}$and $\mathrm{K}^{+}$homeostasis in MA-104 cells. J. Gen. Virol. 1991, 72 Pt 3, 541-547. [CrossRef] [PubMed]

67. Pérez, J.F.; Ruiz, M.C.; Chemello, M.E.; Michelangeli, F. Characterization of a membrane calcium pathway induced by rotavirus infection in cultured cells. J. Virol. 1999, 73, 2481-2490. [PubMed]

68. Lundgren, O.; Svensson, L. Pathogenesis of rotavirus diarrhea. Microbes Infect. 2001, 3, 1145-1156. [CrossRef] 
69. Sack, D.A.; Chowdhury, A.M.; Eusof, A.; Ali, M.A.; Merson, M.H.; Islam, S.; Black, R.E.; Brown, K.H. Oral hydration rotavirus diarrhoea: A double blind comparison of sucrose with glucose electrolyte solution. Lancet Lond. Engl. 1978, 2, 280-283. [CrossRef]

70. Molla, A.M.; Rahman, M.; Sarker, S.A.; Sack, D.A.; Molla, A. Stool electrolyte content and purging rates in diarrhea caused by rotavirus, enterotoxigenic E. coli, and V. cholerae in children. J. Pediatr. 1981, 98, 835-838. [CrossRef]

71. Holloway, G.; Coulson, B.S. Innate cellular responses to rotavirus infection. J. Gen. Virol. 2013, 94, 1151-1160. [CrossRef] [PubMed]

72. Ward, L.A.; Yuan, L.; Rosen, B.I.; Tô, T.L.; Saif, L.J. Development of mucosal and systemic lymphoproliferative responses and protective immunity to human group A rotaviruses in a gnotobiotic pig model. Clin. Diagn. Lab. Immunol. 1996, 3, 342-350. [PubMed]

73. Tabin, R.; Nusslé, D. Rotavirus enteritis in children. Helv. Paediatr. Acta. Suppl. 1980, 1-28.

(C) 2018 by the authors. Licensee MDPI, Basel, Switzerland. This article is an open access article distributed under the terms and conditions of the Creative Commons Attribution (CC BY) license (http:/ / creativecommons.org/licenses/by/4.0/). 